\title{
The Empirical Assessment of English for Specific Business Purpose (ESBP) among Export Development Bank of Iran (EDBI) Staff
}

\author{
Ahmad Moazzen ${ }^{1} \&$ Akram Hashemi $^{2}$ \\ ${ }^{1}$ MA of Islamic Azad University, Roudehen Branch, Iran: Faculty of Foreign Languages and Persian Literature \\ ${ }^{2}$ Correspondence: Akram Hashemi, Faculty of foreign languages and Persian Literature, Islamic Azad University, \\ Roudehen Branch, Iran. E-mail: akram.hashemi2013@gmail.com; ahmad824@yahoo.com
}

Received: May 6, 2015 Accepted: August 10,2015 Online Published: August 16, 2015

doi:10.5539/elt.v8n9p157 URL: http://dx.doi.org/10.5539/elt.v8n9p157

\begin{abstract}
The present study has been conducted with the purpose of exploring the relationship between EDBI staff's General English proficiency and their technical English Writing as well as the way each ESBP and GE courses affect their writing skill. The kind of the study is quasi-experimental with pre-test and post-test, being conducted among EDBI staff in Tehran Branches and Headquarters. In data collection two standard tests were used, namely Preliminary English Test (PET) for homogenous subjects, and also the level of their GE progress at the end of the treatment, and Business English Certificates (BEC) test Level B1, to measure their technical writing skill with appropriate validity and reliability.

The findings indicate that: 1) there was a correlation between subjects' general English proficiency and their business writing proficiency; 2) teaching writing of banking texts significantly improved EDBI staff's General English; 3) teaching writing of banking could significantly improve EDBI staff's Business English proficiency; 4) teaching writing of banking could significantly improve EDBI staff's Business English proficiency more than GE proficiency.
\end{abstract}

Keywords: ESP (English for Specific Purpose), ESBP (English for Specific Business Purpose), EDBI (Export Development Bank of Iran), ELT (English Language Teaching), assessment

\section{Introduction}

Despite the fact that ESP has been widely used over the last three decades, recently there have been considerable debates on its meaning. While some scholars like Barnard and Zemach (2003), call it an area of EFL teaching, in which a narrow range of topics are used, and courses are usually more focused in their aims, others like Dudley-Evans and St. Johns (1998), consider it as an 'approach' to teaching. They define some absolute and variable characteristics for ESP, from which one could conclude that ESP is not necessarily concerned with a specific discipline, and is not aimed at a certain ability range. As Lorenzo (2005) states, "ESP concentrates more on language in context than on teaching grammar and language structures", it could be inferred from his words that another important issue in discussing component of ESP is needs analysis.

\subsection{Statement of the Problem}

With the continuing globalization of markets, widespread recognition of the need for improved General English skills (i.e. writing, reading, listening, speaking) have been growing among banking and finance professionals in Iran. These individuals are finding that general English may not be sufficient to perform job-related communicative functions at a satisfactory level. As a result, the demand for training courses/materials and assessment system tailored to their specific English language needs is growing in Iran's banking and financial sector. One of such organizations is EDBI, whose managers and employees are required to comprehend and easily communicate specific official texts, and even translate them if need arises. Yet, As Yarmohammadi (2005), points out ESP teaching in Iran can be characterized as "language for no specific purposes" since it follows no specific purpose in most of ESP contexts at Iranian Universities. It is being taught through very limited resources to large classes of learners who have no motivation. There is little collaboration between language teachers and content teachers concerning objectives, content and methodology of the course. This can be due to the fact that the 
content of the ESP textbooks are not designed to address the learning needs and expectations of Iranian students. That is, the ESP teachers have access to few materials, including some basic titles on each level, providing ESP vocabulary and reading development, without developing all the skills equally and with little attention to the learners' needs.

\subsection{Research Questions}

1. Is there any significant relationship between General English proficiency and the ability at business /banking writing?

2. Does teaching writing of banking texts significantly improve EDBI staff's General English?

3. Does teaching writing of banking texts significantly improve EDBI staff's business English proficiency?

4. Does teaching writing of banking texts significantly improve General English proficiency more than business English proficiency?

Therefore, this study is hoped to pave the way of establishing a mixed course of General English and ESP course in EDBI to relate staff's General English knowledge to their field of duty. This is supposed to be done by improving their General English proficiency, focusing on business/banking English, in an ESP context in order to enable them to produce technical texts, respecting different fields of international banking affairs, namely foreign transactions, and content-based subject matters in their daily professional duties.

\section{Review of Related Literature}

In order to come to a better understanding of the nature of ESP and its relation with ELT in general, Hutchinson and Waters's (1987) Tree of ELT can be very helpful. In fact this tree is a classification of language teaching sub-branches and how they are related to each other. Here a simplified version of simplified Tree of ELT which is extracted from wen (1996).

\subsection{English for Specific Business Purposes (ESBP)}

Therefore, as Dudley-Evans and St John (1998) explain, it is endowed with the some absolute characteristics as: 1) it is designed to meet specific needs of the learners; 2) it makes uses of the underlying methodologies and activities of the disciplines it serves; and 3) it is centered on the language (grammar, lexis, and register), skills, discourse and genres appropriate to these activities. On the other hand as Ellis and Johnson (1994) suggest that Business English implies the definition of a specific language corpus and highlights particular kinds of communication in a specific context. They believe that what makes Business English different from other varieties of ESP is that "it is often a mix of specific content (relating to a particular job area or industry), and general content (relating to general ability to communicate more effectively, albeit in business situations" (Ellis \& Johnson, 1994).

\subsection{Features of ESBP Language}

Comparatively, as Ellis and Johnson (1994) state, the language of Business English as a special area of ESP has its unique features as follows:

1. Sense of purpose. They (1994), believe that a sense of purpose can be regarded as the most important characteristic of exchanges in the context of business meetings, telephone calls and discussions (ibid: 7). In this sense, all the settings in EBP reflect strong business purposes, that is the language is used to achieve an end or a result, and a successful outcome to the business transaction or event, reflects successful use of EBP.

2. Social aspects. Based on what Ellis and Johnson (1994) point out, in the special contexts of international business, there should be some courtesy to be maintained, tht is, since there is a need for an internationally accepted way of doing things, social contacts are often highly ritualized so that people from different cultures and with different first languages, can quickly feel more comfortable with each another.

3. Clear communication. As Ellis and Johnson (1994) have noted, another characteristic of EBP language is that in business contexts, the language should be both clear in meaning and concise in delivery. In other words, information should be conveyed with minimum risk of misunderstanding and the time for processing also needs to be short. 


\subsection{Some Empirical Perspectives}

\subsubsection{Studies on the Relationship between EFL and ESP}

ESP as a developing branch of EFL, has increasingly expanded in Iran. As Atai (2000) points out, in our country, ESP can best be characterized in terms of EAP programs and the textbooks used in them, therefore EAP currently forms a significant part of curricula for all academic fields at university. These Courses are designed either parallel to their professional studies (called in-study courses) or after finishing their studies (post-study advanced EAP courses, for MA and PhD students). The content of these courses are based on students' future study requirements (e.g. writing academic papers) or related job requirements (e.g. writing official letters). But, based on the researches conducted on assessing the results of these programs, it seems that these courses have not been very successful in fulfilling their aims.

ESP teaching in Iran, as Yarmohammadi (2005) points out, can be characterized as "language for no specific purposes" since it follows no specific purpose in most of ESP contexts at Iranian Universities.

Another shortcoming of the materials presently used in Iranian ESP contexts is "the exclusive attention to the sentence level and consideration of the text as isolated units which results in the distortion of the nature of communication in ESP discourse" (Atai, 2000), therefore reduce their practicality in real, specialized contexts. One of the main reasons for such problems is that ESP materials in Iran are not designed based on needs analysis, which is the core concept of ESP, and therefore do not address learners needs and expectations.

\subsubsection{The Differences and Similarities of ESP and General English}

The nature of relationship between ESP and GE has been a controversial issue. Some educationalists and scholars believe that separating these two from each other is to some extent invalid (e.g. Bloor \& Bloor, 1986 \& Basturkmen, 2008). They argue that there are no appreciated structural differences between Special English and General English. In other words, specialization of ESP courses should not result in the complete separation of parts of the language. As Holme (1996) maintains, pieces of a language or skills cannot be hacked off expecting them to exist independently, because every discipline refers to others and all are built on the same basin of language. A science student who comes to grips with.

It seems a difficult task to draw a clear line where EGP courses stop and ESP courses start, they seem to be highly interrelated. It is generally accepted that specialist of any science field should properly use both ESP and EGP in order to communicate any specialized and non- specialized subject for professionally-oriented activities.

\section{Methodology}

\subsection{Participants}

To accomplish the present research, some (70) EDBI bank experts, working in Tehran branches and head-quarters whose job required learning English, did not have attendance and timing problem, and also were interested in participating in this project, were introduced to the researcher from different departments.

\subsection{Materials}

Different materials and proficiency tests were used in this study as follow:

\subsubsection{Instruments}

The materials were selected from American English File 3 intermediate level (Oxenden, Latham-Koenig \& Seligson, 2008). The reason for selecting this book as a reference for teaching GE was that, in each part of this book, all skills under study (i.e. reading, listening and writing) are included in form of different tasks.

For collecting data researcher has utilized two instruments including a Preliminary English Test (PET) which is a Cambridge university TESOL examination (2011) administrated as PET pre/post test, for assessing learners' General English proficiency progress, if any and a Business English certificate (BEC) test Level B1 (Uses a range of simple and some complex grammatical forms with a good degree of control. Errors do not impede) communication. As pre/post test, to determine their level of proficiency in business English on business writing ability before and after the treatment.

\subsubsection{Procedure}

In order to conduct the research and to verify the research hypotheses the following steps were taken: first, PET language proficiency test was administered to the learners to find out the homogeneity and GE proficiency 
pretest of the groups.

After data analyzing, 60 participants whose scores were at the modified percentile level, were divided into two groups as experimental groups (30 persons) and control group (30 persons). The rest of participants, whose scores were not at this modified range were dropped from the study, therefore two classes each consisting of 30 subjects were held. In the experimental group " $\mathrm{A}$ " the researcher taught ESBP paying attention to grammatical points and concerning language four skills. While using business and banking texts focusing on writing ability extracted from Business Result Intermediate (Grant et al., 2008). The reason for selecting Business Result is that, because the selected units had close relations to technical writing in banking /business field and the level of these books were intermediate, which were suitable for our experimental group, Also Dudley-Evans' (1997) have claimed that ESP courses should be administrated to learners who are at least at Intermediate level of proficiency, and while in control group General English materials from American English File Student Book 3 (Oxenden, Latham-Koenig, \& Seligson, 2008) were taught plus letter styles as informal and formal and e-mail writing .

Before treatment, the researcher gave BEC as a pretest to two groups and the results for every part as writing, reading and listening were computed separately, then experimental group received treatment and control group received placebo. Finally in order to evaluate the effect of separate units of language skills, as well as the overall GE proficiency effect on learners' technical writing ability, the two groups received a PET and BEC as post tests respectively for evaluating their GE and ESP level of proficiency following the treatment.

Examination. The main role of teacher was in selecting and creating the situation based on the learner's business/banking needs, interests and the language skill level and the classes were mostly learner-centered. in order to fulfill the objectives of this study, treatment was administrated by the author himself, who besides being familiar with language teaching techniques and knowing English language, as a MA student of EFL and due to the several years of English teaching experience, is also expert in the specialist field under study, that is banking. This obviated the need to have a subject specialist as a co-teacher, as a result the author did not face difficulties of coordinating subject and language teachers and also time and costs were economized a great deal. Familiarity with the needs of the organization and staff, who are author's co-workers, through informal interviews before starting the treatment, has given the author the opportunity to select the most relevant and appropriate materials.

The subjects, in the Control group (B), received 15 sessions ( 3 in a week) of 90 minutes placebo just on general English (GE). In this group, the researcher carried on a general English course extracted from Select reading book (Gundersen, 2002). According to Erick Gunderson the author of Select reader, Select reading approach exposing learner to a variety of text types and genres helps them develop more effective reading skills. Also readers sharpen their reading, vocabulary building when skills work is tied directly to the content and language of each reading passage. And finally, reading helps student develop writing skills, while writing experience helps students become better readers, so goods readers make good writers (Gundersen, 2002).

\subsubsection{Design}

The design for this study was an experimental one or more specifically as Farhady (2011), puts it, a quasi-experimental research, since except for the selection of subjects which was not based on randomization.

\subsubsection{Data Analysis}

The data gathered in this study was the result of administering 4 tests; Two pre and post PET tests, and two Pre and post BEC tests. In order to interpret the data, the following oprations were carried out.

A) Homogeniety of the subject population was studied.

B) The correlation coefficients of the scores obtained in the PET and BEC tests were calculated through Cronbach's alpha.

C) Two paired smaples T-tests were used to indentify the improvements of the subjects after the treatment.

\section{Results}

The research questions posed in this study were analyzed through the parametric statistical analyses of Pearson's correlation coefficient and Paired samples T-test. That is why the researcher had to confirm assumptions of Normality through considering the Skewness and Kurtosis. In addition to Skewness and Kurtosis, another test of homogeneity, F max, was also carried out to re-confirm the homogeneity of the population under study. 


\subsection{Homogeneity Test}

In addition to the tests of normality, the researcher proved that the subjects enjoyed the same level of general language proficiency prior to the administration of the treatment. It should be mentioned that this operation was not necessary as the plots and the tests of normality were sufficient; however, this operation was also included to assure a more reliant result. The descriptive statistics were carried out for the two groups, the control and the experimental, in order to pave the way to compare the mean scores of theirs. As displayed in Table 5 the experimental $(\mathrm{M}=77.583, \mathrm{SD}=13.87)$ and control $(\mathrm{M}=66.71, \mathrm{SD}=25.73)$ groups showed different means on the PET test.

Table 1. Descriptive statistics PET by groups

\begin{tabular}{lllll}
\hline & $\mathrm{N}$ & Mean & Std. Deviation & Variance \\
\hline Experimental & 30 & 48.9667 & 25.91296 & 671.482 \\
Control & 30 & 51.6000 & 24.69343 & 609.766 \\
\hline
\end{tabular}

In order to test the required assumption of homogeneity of the variance of the two groups, Hartley's Fmax test was carried out (Formual 1). in order to carry out this statistical operation, the bigger variance value is divided by the smaller one. If the Fmax is close to 1, the homogeneity of the variance of the two group can be concluded. The statistic 1.101 , which is very close to 1 , showed that the researcher was safe in concluding that the data depicted the homogeneity of variance for the two group.

$$
\mathrm{F} \max =671.482 / 609.766=1.01
$$

\subsection{Testing Research Null Hyphetetis}

After fulfilling the assumptions of parametric statistical tests, below the statistical operations carried out for this data is provided.

\subsubsection{Research Question 1}

H01: There is no relationship between General English proficiency and the ability at business writing.

In order to find out if, there is any relationship between General English proficiency and the ability at business writing (research question 1), a Pearson correlation test was run. The variables for this test included the learners' scores in their PET (general English proficiency test for intermediate level learners) and their pre and post test BEC writing scores. The Pearson correlation coefficient between the subjects' general English proficiency test scores and their Business English writing proficiency for the pre-test was 0.697 at 0.000 level of significance $(\mathrm{P}<0.05)$, indicating a positive, and large correlation between learners' General English proficiency scores and their Business English writing proficiency for the pre-test. In order to determine how much variance these two variables share, the coefficient of determination for these two variables is determined through squaring the $r$ value (multiply it by itself). To convert this to 'percentage of variance', it is multiplied by 100 . The percentage of the coefficient of determination for these variables is $69 \%$.

In the meantime, The Pearson correlation coefficient between the subjects' general English proficiency test scores and their Business English proficiency test writing for the post-test was 0.659 at 0.000 level of significance $(\mathrm{P}<0.05)$, indicating a positive correlation between learners' General English proficiency scores and their Business English proficiency writing post-test scores. In order to determine how much variance these two variables share, the coefficient of determination for these two variables is determined through squaring the $r$ value (multiply it by itself). To convert this to 'percentage of variance', it is multiplied by 100 . The percentage of the coefficient of determination for these variables is $65 \%$.

The relationship between general English level of proficiency (as measured by the PETALL) and Business English writing level of Proficiency (as measured by the wripre BEC and writingpost BEC) was investigated using Pearson product-moment correlation coefficient. Preliminary analyses were performed to ensure no violation of the assumptions of normality.There was a strong, positive correlation between the two variables, $r=$ $0.697, n=60, p<.0005$, with high levels of general English proficiency associated with high levels of business English proficiency for the BEC writing pre-test. There was also a strong, positive correlation between the two variables, $r=0.659, n=60, p<.0005$, with high levels of general English proficiency associated with high 
levels of business English writing proficiency for the BEC post-test. Thus the first null hypothesis is rejected.

Table 2. Correlation test

\begin{tabular}{lllll}
\hline \multirow{3}{*}{ PETALL } & wriprBEC & WritingpostBEC & PETALL \\
\cline { 3 - 5 } & Pearson Correlation & $.697^{* *}$ & $.659^{* *}$ & 1 \\
& Sig. (2-tailed) & .000 & .000 & \\
$\mathrm{~N}$ & 60 & 60 & 60 \\
\hline
\end{tabular}

**. Correlation is significant at the 0.01 level (2-tailed).

\subsubsection{Research Question 2}

H02. Teaching writing of banking texts does not significantly improve EDBI staff's General English.

In order to study the null hypothesis, teaching English writing of banking texts does not significantly improve EDBI staff's General English, the improvement of the experimental group's General English before and after the treatment, was studied through a Paired samples t-test. In so doing, the researcher compared the difference between the PET test scores before and after the treatment. The results are presented in the tables below.

According to Table 4.7, the probability value is 0.018 (Table 3 ) for the experimental group. As this value is less than .05 , it can be concluded that there is a significant difference between the scores after and before the treatment.

In order to find out which set of scores is higher (Pre-test and Post-Test, the Mean scores for each of the two sets of scores is studied. The mean business English proficiency score for the pretest is 77.05 and the mean score for the post-test is 82.08 (Table 3). Therefore, we can conclude that there was a significant increase in the mean scores from Time 1 (prior to the treatment) to Time 2 (after the treatment). This difference does not seem to have been taken place by chance. To put it in a nutshell, A paired-samples t-test was conducted to evaluate the impact of the treatment on students' PET test scores. There was a statistically significant increase in general English proficiency of the subjects (as measured through PET test) from Pretest $(M=77.5, S D=12.93)$ to Post-test $(M=$ 82.08, $S D=17.82), t(29)=-2.500, p<.0005$ (two-tailed). The mean increase in general English proficiency scores is 5.3 with a $95 \%$ confidence interval ranging from -9.15 to -0.915 (Table 3 ). Therefore, the null hypothesis is rejected.

Table 3. Paired samples T-test for the experimental group

\begin{tabular}{|c|c|c|c|}
\hline \multirow[b]{2}{*}{ Pretest exp. } & \multicolumn{2}{|l|}{ Mean } & Standard Deviation \\
\hline & \multicolumn{2}{|l|}{77.05} & 12.93 \\
\hline \multirow[t]{3}{*}{ Posttest exp. } & \multicolumn{2}{|l|}{82.08} & 17.82 \\
\hline & \multicolumn{2}{|c|}{$95 \%$ Confidence Interval of the Difference } & $\mathrm{t}$ \\
\hline & Lower & Upper & \\
\hline Pair 1 & -9.151 & -.915 & -0.2500 \\
\hline
\end{tabular}

The same procedure was run for the control group in order to study the improvement of control group's General English before and after the placebo. This was carried out through a Paired samples t-test. In so doing, the researcher compared the difference between the PET test scores before and after the treatment. The results are presented in the tables below.

According to Table 4, the probability value is 0.661 for the control group. As this value is bigger than.05, it can be concluded here is no statistically significant difference between your two conditions, pre and post tests.

In this way, we can conclude that there is a statistically significant difference between mean scores on generally proficiency test (PET) between experiment and control groups. In this way, it can be concluded that the null 
hypothesis for this research question is rejected, and teaching English writing of banking texts does significantly improve EDBI staff's General English.

Table 4. Paired samples T-test for the control group

\begin{tabular}{|c|c|c|c|c|c|}
\hline \multirow[b]{2}{*}{ Pretest exp. } & \multicolumn{3}{|c|}{ Mean } & \multicolumn{2}{|c|}{ Standard Deviation } \\
\hline & \multicolumn{3}{|c|}{65.25} & \multicolumn{2}{|l|}{24.68} \\
\hline \multirow[t]{3}{*}{ Posttest exp. } & \multicolumn{3}{|c|}{64.90} & \multicolumn{2}{|l|}{25.97} \\
\hline & \multirow[t]{2}{*}{$\mathrm{Df}$} & \multicolumn{2}{|c|}{$95 \%$ Confidence Interval of the Difference } & \multirow[t]{2}{*}{$\mathrm{t}$} & \multirow[t]{2}{*}{ Sig (2-tailed) } \\
\hline & & Lower & Upper & & \\
\hline Pair 2 (control group) & 29 & -1.266 & 1.966 & 0.443 & 0.661 \\
\hline
\end{tabular}

\subsubsection{Research Question 3}

H03. Teaching writing of banking texts does not significantly improve EDBI staff's business English proficiency.

In order to test the null hypothesis, teaching writing of banking texts does not significantly improve EDBI staff's business English proficiency, Paired samples t-tests were run. First, the test was run for the experimental group. The results are presented in the tables below. The probability value is .000 (Table 5) for the experimental group. As this value is less than.05, it can be concluded that there is a significant difference between the scores after and before the treatment.

In order to find out which set of scores is higher (Pre-test and Post-Test, the Mean scores for each of the two sets of scores is studied. The mean business English proficiency score at Time 1 is 67.66 and the mean score at Time 2 is 82.08 (Table 5). Therefore, we can conclude that there was a significant increase in the mean scores from Time 1 (prior to the treatment) to Time 2 (after the treatment). This difference does not seem to have been taken place by chance. To put it in a nutshell, A paired-samples t-test was conducted to evaluate the impact of the treatment on students' scores on the Business English Proficiency. There was a statistically significant increase in business English proficiency scores from Pretest $(M=67.66, S D=13.24)$ to Post-test $(M=82.08, S D=17.82), t$ (29) $=-7.231, p<.0005$ (two-tailed). The mean increase in business English proficiency scores is 14.42 with a $95 \%$ confidence interval ranging from -18.49 to -10.33 (Table 5). Therefore, $\mathrm{Ho}_{3}$ is rejected.

The same test was also run for the control group. The results are presented in Table 6, below. The probability value is .059 for the control group. As this value is more than 0.05 , it can be concluded that there is not a significant difference between the scores after and before the placebo.

A paired-samples t-test was conducted to evaluate the impact of the placebo on students' scores on the business English proficiency (Table 4.8). There was a statistically insignificant increase in business English proficiency scores from Time $1(M=56.91, S D=56.01)$ to Time $2(M=57.73, S D=26.79), t(29)=-1.96, p>0.0005$ (two-tailed). In this way, the researcher is safe to conclude that teaching of business English writing could significantly improve EDBI staff's business English proficiency. 
Table 5. Paired samples T-test for the experimental group

\begin{tabular}{|c|c|c|c|c|c|c|c|}
\hline \multirow[b]{2}{*}{ Experimental group pre-test } & \multirow{2}{*}{$\begin{array}{l}\text { Mean } \\
67.66\end{array}$} & \multicolumn{6}{|c|}{ Std. Deviation } \\
\hline & & 13.24 & & & & & \\
\hline Experimental group post-test & 82.08 & 17.82 & & & & & \\
\hline Pair 1 & Mean & Std. & \multicolumn{2}{|c|}{$\begin{array}{l}95 \% \text { Confidence Interval } \\
\text { of the Difference }\end{array}$} & $\mathrm{T}$ & Df & $\begin{array}{l}\text { Sig. } \\
\text { (2-tailed) }\end{array}$ \\
\hline EXPRE - EXPPOST & 1.44 & 10.91 & $\begin{array}{l}\text { Lower } \\
-18.49420\end{array}$ & $\begin{array}{l}\text { Upper } \\
-10.33913\end{array}$ & -7.231 & 29 & 0.000 \\
\hline
\end{tabular}

Table 6. Paired samples T-test for the control group

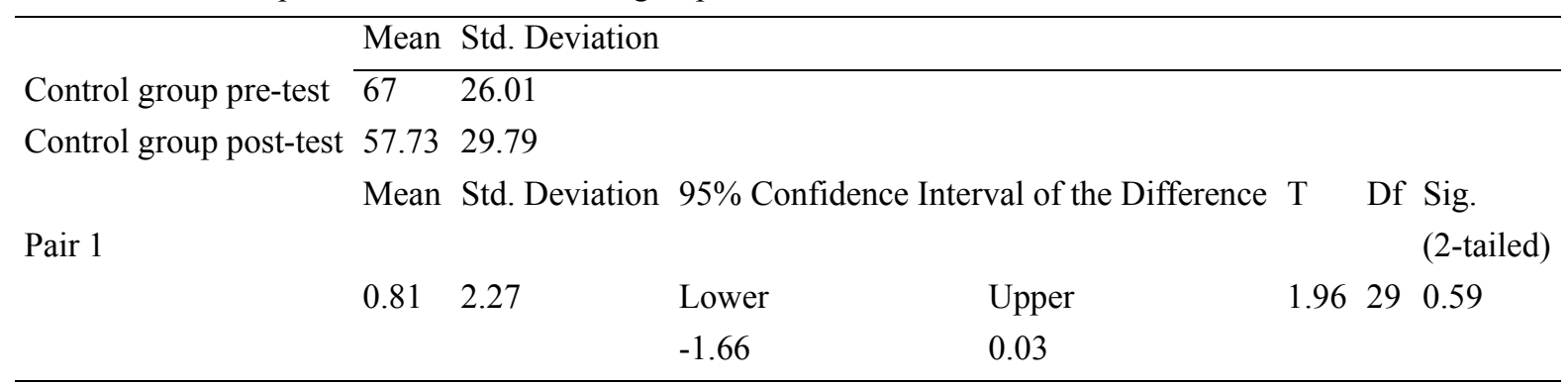

\subsubsection{Research Question 4}

H04. Teaching writing of banking texts does not significantly improve General English proficiency more than business English proficiency.

In order to study hypothesis 4 , the effect size of teaching writing of banking texts had to be studied. As stated in 4.2.2 and 4.2.3, the treatment, teaching writing of banking texts, had significant and meaningful effect on subjects' general English scores and their Business English scores, as well. Nonetheless, In order to calculate the effect size for the treatment, the eta square was calculated. The eta square for this difference in the means for the effect of teaching banking writing on subjects' general English scores was 0.17. According to Cohen (Cited in Pallant, 2011), it can be concluded that there is a small effect in the general English scores -measured through PET test- obtained before and after the treatment.

In order to calculate the effect size for the treatment on the business English of the subjects, the eta square was calculated. The eta square for this difference in the means was 2.40. According to Cohen (cited in Pallant, 2011), it can be concluded that there is a large effect, with a substantial difference in the business English proficiency scores obtained before and after the treatment. Obviously, it can be concluded that the effect of the treatment for the development of business English writing has been bigger. In this way, the researcher is safe to conclude that teaching of banking writing has a bigger effect on the improvement of subjects' business English.

\section{Conclusion}

Data analysis proved that the population under study was homogeneous; however, as convenience sampling was put into use, due to the limitations, the findings of this study are limited to the population under study. It is not therefore suggested to expand these findings to other populations.

The results obtained through the Correlation test for the first research question could obviously show that there was a correlation between subjects' general English proficiency and their business writing proficiency (Table 2).

As with the second research question, results obtained through the independent $t$-test indicated that there was a significant difference between the experimental and control groups' mean scores on pre and posttests (Table 3). However, for the control group (Table 4), no significant difference was observed. Therefore, it can be concluded that teaching writing of banking texts significantly improved EDBI staff's General English.

The third hypothesis was also studied through another T-test. The results showed that there was a significant difference between the experimental groups' mean scores on the pre and posttests (Table 5). However, for the 
control group (Table 6), no significant difference was observed. Therefore, it can be concluded that teaching writing of banking could significantly improve EDBI staff's Business English proficiency.

As with the fourth hypothesis, the eta square for the difference in the means for the effect of teaching banking writing on subjects' general English scores, as well as their business English scores, were calculated. It was found out that the effect of teaching business English writing on the experimental group's business English proficiency was bigger.

In this way, it can be concluded, on the one hand, that teaching business English writing has been effective on both General and business English of subjects. Nonetheless, the means of the experimental group, along with their effect size, show a bigger effect on business English.

Ellis and Johnson (1994) suggest that Business English implies the definition of a specific language corpus and highlights particular kinds of communication in a specific context. This fast growing branch of ESP (Dudley-evans, 1994), is a special area of English language that ESP has its unique features. The findings of this study support this idea in the way that the findings show that those who take use of business English materials do improve their business English writing as a results of the EBP they receive.

\section{References}

Atai, M. R., \& Tahririan, M. H. (2003). Assessment of the status of ESP in the Iranian higher education system. In proceeding of $L S P$, communication, culture and knowledge Conference.UK: Guilford University.

Barnard, R., \& Zemach, D. (2003). Materials for specific purposes. In B. Tomlinson (Ed.), Developing materials for language teachers (pp. 306-325). London: Cromwell Press.

Basturkmen, H. (2006). Ideas and options in English for specific purposes. Mahwah, NJ: Lawrence Erlbaum

Basturkmen, H. (2010). Developing courses in English for specific purposes. Basingstoke, UK: Palgrave Macmillan. http://dx.doi.org/10.1057/9780230290518

Bloor, M., \& Bloor, T. (1986). Languages for specific purposes: Practice and theory (occasional paper no. 19). Dublin: Trinity College.

Dudley-Evans, T., \& St John, M. J. (1998). Developments in ESP: a multi-disciplinary approach. Cambridge: Cambridge University Press.

Dudley-Evans, T. (2001). English for specific purposes. Cambridge: Cambridge University Press. http://dx.doi.org/10.1016/S0889-4906(01)00034-5

EDBI. (1391). In Annual of Export Development Bank of Iran. Retrieved June 17, 2014, from http://en.edbi.ir/lang-en/EDBI-At-a-Glance/default.edbi

Ellis, R. (1997). The empirical evaluation of language teaching materials. ELT Journal, 51(1), 36-42. http://dx.doi.org/10.1093/elt/51.1.36

Ellis, M., \& Johnson, C. (1994). Teaching business English. Oxford: Oxford University Press.

Farhady, H. (1994). On the specificity of purpose in ESP. In A. Miremadi (Ed.), the proceedings of the second conference on theoretical and applied linguistics (pp. 63-82). Tehran: Allameh Tabatabai University Press.

Farhady, H. (2005). Reflections on and directions for ESP materials development in SAMT. In G. R. Kiany \& M. Khayamdar (Eds.), Proceedings of the First National ESP/EAP Conference, 3, (pp. 2-32). Tehran: SAMT Publications.

Gan, H. (1996). English for International Business Communication. Shanghai: Shanghai Science and Technology Press.

Grant, D., Beade, K., Duckworth, M., \& Holloway, M. (2008). Business Result Pre-intermediate and Intermediate. Oxford: Oxford University Press

Gundersen, L. L. E. (2002). Select reading book. Oxford: Oxford University Press.

Holme, R. (1996). ESP ideas: Recipes for teaching professional and academic English. Essex, England: Longman.

Hutchinson, T., \& Waters, A. (1987). English for specific purposes: A learning-centered approach. Cambridge: Cambridge University Press. http://dx.doi.org/10.1017/CBO9780511733031 
Johns, A. M., \& Dudley-Evans, T. (1991). English for specific purposes: international in scope, specific in purpose. TESOL Quarterly, 25(2), 297-314. http://dx.doi.org/10.2307/3587465

Lorenzo, F. (2005). Teaching English for specific purposes. UsingEnglish.com. Retrieved October 25, 2013, from http://www.usingenglish.teaching-english-forspecific-purposes-esp.html

Pallant, J. (2011). SPSS survival manual (4th ed.). Buckingham: Open University Press.

Payment, O. (1992). In Dictionary of Finantial and Business Terms. Retrieved June 17, 2014, from https://www.wiziq.com/tutorial/23752-Dictionary-of-Financial-and-Business-Terms-pdf

Stern, H. H. (1992).Issues and options in language teaching. Oxford: Oxford University Press.

St John, M. (1996). Business is booming: Business English in the 1990s. English for Specific Purposes, 15(1), 3-18. http://dx.doi.org/10.1016/0889-4906(95)00023-2

Wen, C. F. (1996). The relationship of learner variables to scores on CET band-4. Foreign Language Teaching and Research, 28(4), 33-39.

Yarmohammadi, L. (2005). ESP in Iran from language planning perspective. Proceedings of the First National ESP/EAP Conference, 2, (pp. 2-20). Tehran: SAMT Publications.

\section{Copyrights}

Copyright for this article is retained by the author(s), with first publication rights granted to the journal.

This is an open-access article distributed under the terms and conditions of the Creative Commons Attribution license (http://creativecommons.org/licenses/by/3.0/). 